\title{
Social Matter and Research in Nigeria: Why Theories Often Falter in Predicting Local Data
}

\author{
Franklins A. Sanubi ${ }^{1}$ \\ ${ }^{1}$ Department of Political Science, Delta State University, Abraka, Nigeria \\ Correspondence: Franklins A. Sanubi, Department of Political Science, Delta State University, Abraka, Nigeria. \\ E-mail: sanubi@yahoo.co.uk; fasanubi@delsu.edu.ng
}

Received: March 24, 2015 Accepted: April 20, 2015 Online Published: May 27, 2015

doi:10.5539/jpl.v8n2p108 URL: http://dx.doi.org/10.5539/jpl.v8n2p108

\begin{abstract}
The study examines the relevance of genuine social data in the verification of social theories under the scientific study of social matter. It is premised in social research methodology drawing instances from varied social science matter as they are presently disposed in Nigeria. It adopts a historical research methodology to carefully analyze the performance of some selected social theories namely: the relative-deprivation, frustration-aggression, religious-fundamentalism and ethnic theories using local experiences and data for evaluating them. The study observes that these theories have performed poorly due to the nature of local social research data applied in verifying them. The study believes that these data have become biased due inter alia to the low level of confidence in their sourcing individuals or institution and the fact that some of these data have been poorly extracted initially. It recommends among other things, a growing of the confidence in the nation's research efforts and institutions and a patronage of local researches through not only provision of funding support for research and scholarship but also in the implementation of existing social research outcomes and recommendations. These the study believes would promote the furtherance and use of more genuine data in social researches in Nigeria.
\end{abstract}

Keywords: Nigerian Social Research, Philosophy of Social Science, Research Data, Social Research Methods, Social Theories

\section{Introduction and Problem Statement}

Prediction is probably the most important of the major hallmarks of any traditional or modern science. The ease with which a process can prognosticate on the future behavior of a social variable defines much more the mark of science in such a social process than the other notable qualities of science. Some of the other qualities are: that "science" is objective (having a known beginning and endpoint); logical, that is, following a natural line or sequence of reasoning (Smart, 1931); systematic, that is, having an organized integrated body and procedure; replicable, that is, capable of being repeated with exact outcomes; and inter-subjective - capable of simultaneous confirmation by several authorities. Scheff et al, (2006) believes that inter-subjectivity involves agreement-sharing between two subjective personalities. Although the quality of an art work may well be evaluated through a process of inter-subjectivity (Soddu, 2010) which might ultimately bring some argument of "science" into Fine Arts, all science however is inter-subjective in character and must be capable of dual or multiple verification by distinct personalities.

However, social matter, unlike other natural phenomena, is the most fluid to predict given a specimen sample data. Yet human behavior, the primary object of social research, remains a common and recurring subject matter in everyday life. The uniqueness of human behavior as an object of scientific investigation is cemented inter alia on the fact that its fluidity is typified by its environment - whereby social assumptions, laws or hypotheses become valid only in particular cultural settings and may not fit into other social prisms (cultures) in the same way as in their originating social milieu. Hence social laws, if any, are ethnocentric (that is, geographically relevant) and do not provide strong force of their universal acceptance as in the natural science. Therefore, in the philosophy of the social sciences, there may be no universal laws applicable in the entire discipline of the social sciences, rather there are ceteris paribus laws otherwise referred to as "non-universal laws". Notwithstanding the attempt by Reutlinger, (2011) to justify the "validity" and "relevance" of social laws, it is evident that these laws (that is, social science laws) cannot fit into every social milieu and their applications and or effectiveness can 
only be defined within the context of the given society. Consider for instance, the use of comparative samples of social data on marital infidelity as predictor of divorce rate among married couples. We hypothesize here that data samples from local African societies and those from other (particularly Western and American) regions may produce divergent results between these regions. This is because the explanatory variable for the divergent result, which may lie within the social fabric of the particular African society, may be non-existent in societies in the other regions. This is notwithstanding the fact that all parties in marriage relationships in the Western societies may have equal level of social awareness and justice, especially the women party in such marriages who are often more on the receiving end in divorce (Rosen, 2009). Some authorities have argued that there can be no laws in social science as the subject matter in this field of learning is wrapped in "perplexity of humanity and its cultural constructs which are more enigmatic" (Feynman,1981) than the static molecules and other predictable (easily controllable) phenomena being studied in the world of natural science. Referring to Feynman, Pomery (2014) posted the former's belief that the enterprise of social science though not entirely doomed to fail, may never fully succeed as a scientific discipline. Attia (2012) had also published excerpts of his interview with the late physicist (Richard Feynman) in his blog quoting the latter's strong stance on the futility of a social science enterprise, thus:

Because of the success of science there is a kind of pseudoscience, social science which is not a science. They don't do scientific...they follow forms...you gather data, you do so and so and so forth but they don't get any laws. They haven't found anything, they haven't got anywhere yet, maybe someday they will...

Against such background, it is not a matter for much contestation by researchers, analysts and policy watchers in Nigeria to observe that local social data do not often provide reliable evidence for predicting behavior of social variables in Nigeria albeit at micro or macro levels of analysis. Thus while data on the per capita Gross National Product(GNP) of a hypothetical developed Western economy may provide very substantial (if not holistic) information about the social behavior of variables (for example, the living standards of the people) in that economy, or while a specimen data on a voting exercise in a political process may provide a significant (if not holistic) prediction of the behavior of political variables (such as the choice and conduct of actors, agencies, institutions or the electors), in Nigeria, such data are often unreliable, notwithstanding the individual or institution which obtained them in situ. For instance, based on the current Nigerian experience so far in the democratic dispensation, it is often misleading or highly spurious to use election results in Nigeria, at whatever levels - local, state (regional) or national - to make research predictions on voters' choice of candidates in a state election or on the electoral victor's popularity and acceptance. Anyone attempting to do such research must be sufficiently versed in, as well as ready and equipped for, the process of controlling the somewhat "uncontrollable" intervening variables with which the local sociopolitical system is replete.

Local social researchers in Nigeria, from the foregoing, have had to put much effort, perhaps more than their international contemporaries researching on similar matter, if their researches are to be counted worthy of any significant recognition. For by not merely importing international theories, no matter their level of universal acceptability and testability, the local social researchers have had to face daunting tasks of collecting, collating and sifting local data as research evidence to try and establish some form of causality or other relationships (if any) existing between a given set of social variables.

The factors which explain in part, the faltering results of scientific investigation of social matter in Nigeria are diverse and multifaceted. If in the general sense, scientific theories, albeit social or natural, provide a guide to the behavior of quasi-experimental or experimental variables respectively, there is a lot to be expected from local social researches in Nigeria to provide sufficient platform(s) on which local data used therein can be put up for international recognition.

Against the background of current development challenges in Nigeria where typically the state has had to confront harsh economic and social vagaries (such as plummeting crude oil prices and an imploding social system due to growing population pressure), policymakers in Nigeria have made resonate calls for new social research as a source for redress. The current study is justified by the need to identify the factors which often "intervene" in the outcome of social researches that are based on local data obtained in Nigeria - an understanding upon which current stakeholders, policy makers and researcher may dilate.

\section{Theory in Social Inquiry: Brief Discourse of Relevance}

A theory may be seen as a simplified explanation of the way a system works. It is an abstraction from reality designed to provide a better understanding of the workings of a real world system. This perception presupposes that for a theory to be possible, there must be a system - an organism with integrated parts performing regular 
functions and maintaining a pattern of activity in order to sustain the body and realize its common goals as a whole unit (Bettalanffy,1968, Ryan,1995, Easton,1965, Parsons,1951). This implies that a theory cannot easily be used to explain irregular non-systemic events or arts. In the realm of natural science, it is easy to conceive of a real system. However with social matter, the conception of a system is subject to several laborious interpretations and that also involving a lot of human efforts - what Feynman (1981) called "perplexity". Hence while each of economic system, political system, and social system (or other related systems) provides a guide to the working of a supposedly organized form of social matter, theorizing in any of these systems is not simple as the common subject matter in them all - human behavior - is very fluid and vulnerable to constant change. To construct theories based on real world situations that is very complex, that takes account of all, or even most of all that complexity, "would be beyond the capacity of any human brain" (Stonier \& Hague,1972). Theories therefore are designed, presented and explained in abstract terms since they are representations of a larger more complex real world. Consequently, theories are constructed in form of symbolic chart diagrams, mathematical models, equations or other forms of representation. Most social theories are constructed to explain the existence of some form of relationships, often (but not always) with a goal of establishing causality between a set of independent and dependent variables as a scientific inquiry. They are often constructed based on the testing of some tentative statements called "hypotheses". Upon these hypotheses are models built to enable the inquirer test the strengths of the hypotheses and then the ultimate theories arising there from. The strength of a model lies in its validity and its testability which among other factors derive from the consistency and reality of its assumptions, its predictive power, the amount of information it provides, its generality and its simplicity (Ekpo \& Ndebbio,1988). The procedure for testing a theory in all the social sciences is the same. For instance, Koutsoyannis (1988) outlined the procedure for testing an economic theory, thus:

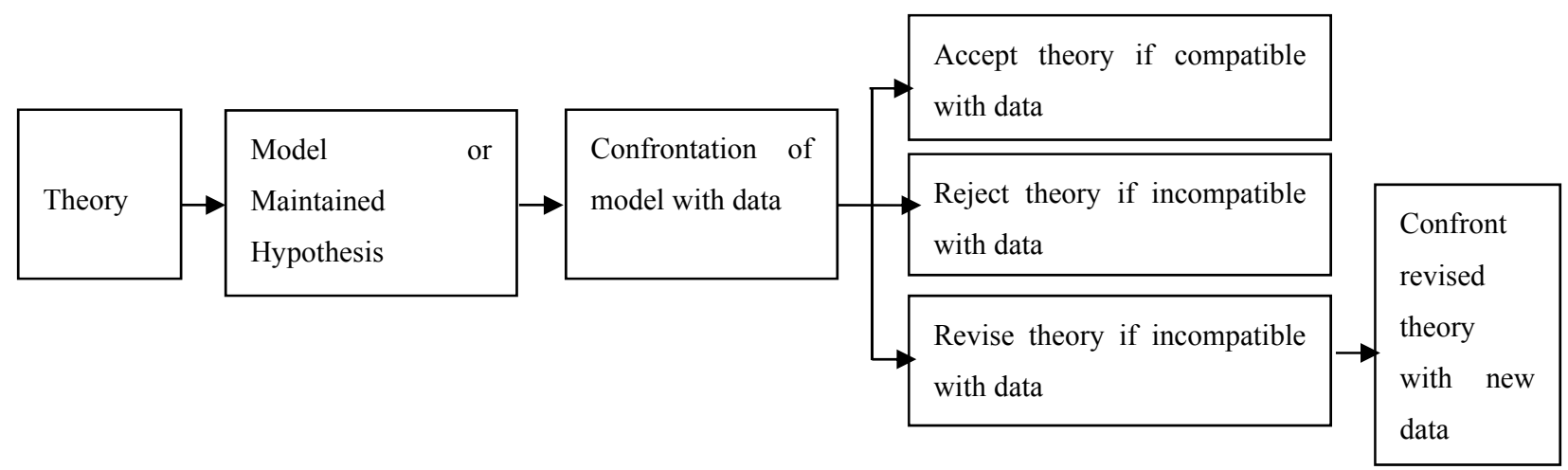

Figure 1. Theory validation process - adopted from Koutsoyannis (1998)

An acceptance of a theory therefore is a supposition of its validity. If the data used in testing the theory are drawn from real world situations, then the theory can be used to explain the behaviour of the larger real world. Thus, most social theories have been used to explain the workings of social systems, political systems, economic systems and being able to predict the behaviour of actors (subsystems) in such organized societies.

In the scientific method or approach to research inquiry, theories provide explanation for the observed behaviour of a social phenomenon upon a sufficient accumulation of evidence derived from testing relevant data (Zimmerman, 2012) - such as data on an actor in the social system. In the Dollard, Miller and others' Frustration-Aggression-displacement for instance, theory is used to explain why certain persons engage in violence as a result of being "pushed to the wall" by other actors in a given socio-political or economic system. According to this theory, when an individual gets frustrated over the action of another person and does not seem to be able to confront the source of the frustration, he gets into an aggressive behaviour - an aggression that often gets displaced on to other innocent and originally uninvolved persons (Dollard, et al, 1939). Theories provide a mirror through which societal issues can be viewed. They provide background for the formulation of new hypotheses upon which further "scientific" researches can be conducted - they actually build pathways for further knowledge and research as they provide the principles guiding their conduct. Theories are a precursor to social laws, if any. They also provide basis for the validation of scientific results and the determination of their suitability and universal acceptance. Social theories actually reveal the scientific status of the social world and help establish knowledge gaps between existing and unknown social phenomena. Social theories stimulate research logic on which social relationships are constructed. Theories according to Horowitz (1985) as cited in Danjibo (2014), ' $\ldots$ provide a useful starting point, and not just because they afford us a glimpse of the state of 
the art against which to develop new connection". A social theory is so important in packaging a social research and could be likened therefore to a shopping-basket often picked by shoppers at the entry of supermarkets, into which every article (good) purchased is put and then carried. Thus if the carriage is fragile, the goods would be vulnerable to fall or destruction. Theory therefore is a useful carriage for research items. The relevance of theory in social inquiry cannot therefore be underestimated if social matter is to be subjected to scientific analysis.

\section{Performance of Social Theories in Nigeria}

The relevance of theory in social research highlighted in the preceding section appeals a lot to the social researcher, working with reliable data in organized social milieus operating in "best practice" cultures. However, because of the fluidity of human behavior and the ethnocentric nature of social laws, the testability and hence validity of such social theories is open to unending questions. Yet, in developed societies where human activity is regulated by commonly acceptable mediums (such as constitution - written or unwritten, rule of laws, human rights, national consciousness or philosophy) it is easier to validate a social theory against the regular pattern of conduct of majority of the people in that society and then the inquirer can at least predict human behavior there from under given conditions.

However, in societies where the afore-stated mediums are ineffective even if present, theories can only but falter to predict the exact (or near-exact) behavior of research data. Social matter in Nigeria falls into this latter category. Social researchers in Nigeria who conduct scientific studies must be intrigued by the paucity of relevant data and having to work with available ones or create new ones, most of which provide insufficient if not misleading or unreliable research information. Consider for instance how much of reliability issues would surround the use of secondary data collected from the Nigeria Police Department in Lagos in the study by Atubi, (2009) working on transportation injuries in Lagos State of Nigeria. It is quite evidential in Nigeria that many of the accident cases in major cities, let alone the Lagos metropolis are unreported or unaccounted for (but for some recent efforts by the Road Safety Corps - an agency recently created by the federal government of Nigeria for that purpose). Besides, there is a common pejorative level of confidence in the Nigerian police capacity for proper record-keeping (as in other issues it handles) in its present disposition. Under such premise therefore, theories would falter.

In assessing the performance of some social theories in Nigeria, only a few of the many current theories are mentioned for immediate analysis here not merely for time and space constraints but more importantly for the focus of this research. The few social theories selected for this purpose therefore are the relative-deprivation, frustration-aggression, religious-fundamentalism and ethnic theories. The list of social theories being used in the social sciences is however unending. In fact, the bulk of knowledge in the social sciences still exist in theory form and no single article (or research report) can possibly touch on all in limited settings such as this offers. Nevertheless, attempt is being made here to provide discussions on the performance of the some of the theories selected for this analysis on the grounds that they have featured very often in Nigeria's current economic and social predicaments. Thus, when the Niger Delta militancy evolved among segments of the youth in the region, the event was dispatched by analysts under the Ted Robert Gurr Relative Deprivation and FrustrationAggression theories (Afinotan \& Ojakorotu, 2009; Walker \& Smith, 2001). There is a continuing hypothesis that the crises in the Niger Delta are politically minded. It is believed for instance that "for Niger-deltans, the underdevelopment of their region is the consequence of deliberate policies of discrimination; deprivation and criminal neglect that minority groups in general have suffered from in the country" (Osaghae, Ikelegbe, Olarinmoye \& Okhomina, 2007)

The militants who view economic marginalization as the cause of their not having adequate resources (value attainment) to help them sustain their lifestyles (value expectations) in a ravaged economy that currently offers no immediate future for the youth, had seen this gap between their expectations and their capability as an impetus to resort to violence in the pursuit of their mainly economic courses. But the aftermaths of the crisis inter alia was, the establishment of an Amnesty programme which sought to rehabilitate some pockets of militants who traded-off their arms for some government "carrot" programmes while a very few of these have risen to prominence and become wealthy and influential (albeit injudiciously). Yet a great majority of the Niger Delta youths (many of whom are unemployed college graduates, with some having additional entrepreneurial skills) for which the initial militant activism was purportedly executed, like other youths in marginalized minority areas in Nigeria, remain marginally poor, economically, socially and morally depraved (Tenuche,2009). Relative deprivation and or frustration-aggression have thus failed to provide a total template for explaining the Niger Delta militarism as several intervening issues lie underneath these theoretical assumptions - such as the role of key Niger Delta elite and the agenda of political actors in the region who may have seen the youth militancy as springboard for launching into political prominence and ascendancy, among other factors. 
Within another theoretical prism, this time of the theory of religious fundamentalism, Boko Haram insurgency in the Nigeria's northeast was originally theorized as an Islamic propagation programme (Danjibo, 2009, Obah-Akpowoghaha, 2013) just as an earlier movement - the Sharia law judicial system - has been similarly theorized. Other analysts (for instance, Usman, 2015) even suggest that the movement is economically minded and these specifically hold on to the unemployment and poverty variables as being responsible for the sect's activities. Upon confrontation with data on government's secularization/dialoguing initiative, the religious fundamentalist theory of the Boko Haram had instead produced results that now become clearer beyond the realms of mere Islamic propagation - that of an independent Islamic state (a variant of ISIS in the Syrian region). It should not be inappropriate to assume here that there is an existence of a strong synergy between the operators of Boko Haram and the Syrian-based ISIS and possible transactions between these, as the former had operated in the same manner as the ISIS. The connection is not unrealistic to imagine as an international news network - the Cable News Network, CNN published a filmed documentary in which the Boko Haram leader was purportedly quoted to have pledged allegiance to ISIS. According to a report credited to its reporters Elbagir, Cruickshank \& Tawfeeq (2015) 'Boko Haram, the Nigeria-based Islamist terror group, has pledged allegiance to ISIS... purported to be from Boko Haram's leader, Abubakar Shekau. In the audio, which was posted online Saturday, the speaker says Boko Haram is announcing its "allegiance to the Caliph of the Muslims, Ibrahim ibn Awad ibn Ibrahim al-Husseini al-Qurashi," which is another name for ISIS leader Abu Bakr al-Baghdadi'

Earlier, when the sect declared a caliphate over seized territories in Nigeria as reported again by another international (German) news network, Deutsche Welle (2014), the Boko Haram leader, Abubakar Shekau was quoted to have thanked Allah "who gave victory to our brothers in Gwoza and made it part of the Islamic caliphate," Social researchers working on data based on religious (albeit Islamic) fundamentalism should therefore expect faltering results on Boko Haram insurgency for while the sect's slogan comprises renunciation of western education and repudiation of all "infidels" (those who do not accept the Islamic faith), the development of the sect's activities in the Nigerian State shows that both Christians and Muslims are equally targeted for destruction in the series of terrorist attacks launched so far by the Boko Haram sect. Quite ironical to the sect's philosophy is the observation that suicide bombers engaged by the sect actually operate not only on weekends or other weekdays/nights but also on Fridays at prayer grounds or mosques killing people, some of whom may be regarded as the "fathers of the Islamic faith" in the Nigerian state. Besides, by the sect's principle of renunciation of western education, it would be theoretically appropriate to agree with Obanikoro (2014) that the prosecutors of its objectives should be stack illiterates with minimal, if any, of western educational background. However, a cursory review of the sect's leadership and followership activities would show that some of these people (and or their apologists) are among the highly learned group within the northern elite class in the Nigerian state - majority of who have perfected the use of modern information technology such as the internet, social media platforms and advanced telephony. Beyond mere religious hypotheses, the Boko Haram insurgency has other explanations. Religious theories therefore would falter in testing data on that social phenomenon - Boko Haram.

Ethnicity perhaps reverberates as a strong political economy tool in a contemporary democracy that is highly structurally heterogeneous like Nigeria. Expectedly, several studies (Amoo,1997; Ehwarieme,2012; Elbadawi and Sambanis,2000; Horowitz, 1985; Huber, 2011; Otite, 1990 and Vande, 2012) have focused on this issue while some try to establish the magnitude of "ethnicization" as a problematic in political and social determinism. In these studies, ethnic theories have been used to elucidate the role key political actors play in public policy and decision-making. In Ehwarieme (2012) for example the focus is on establishing the place of ethnic prejudice in the determination of voter's choice among electorate in selected ethnic groups in the Nigerian state. There are three dominant ethnic groups in Nigeria namely; the Hausa/Fulani in the north, the Yoruba in the southwest and Igbo in the southeast beside which are several other smaller groups. Beside these however, in smaller regions or states within Nigeria, are other heterogeneous groups in which political and socio-economic courses are dominated by the majority ethnic group in such geopolitical constituencies or states. Ethnic theoretical expectations in Nigeria would be that political choice is dictated by the political actors appealing to ethnic and or primordial cleavages of the electorate during state or national elections. However, as Ehwarieme (2012) observed, much paradoxically, of the voting exercise in the southern states (particularly Delta State) in the 2007 and 2011 election slots, state elections did not respond to ethnic signals nor did the process appeal to any such ethnic or primordial sentiments as would otherwise have been hypothesized. Voting performance however traversed ethnic boundaries with voting results indicating in some instances where the victorious candidates won in the alternate ethnic constituencies other than those in locations of their own ethnic origins. In the 1993 annulled presidential elections in Nigeria in which a southern Muslim of Yoruba ethnic extraction purportedly won overwhelmingly in all the geopolitical regions (Aluko, 1994) even with majority votes coming from 
non-Yoruba states and regions, the performance of ethnicity as a theory in explaining the voting choice among the Nigerian electorate have also faltered. Yet political economy decisions (such as in the choice of project location or establishment of a state institution) have often appeared and been rationalized as following ethnic fundamentalist line of thinking.

If the degree of impunity, due process and transparency are at least theoretical (if not practical) issues characteristic of non-democratic states, theories on these variables would also falter in predicting local research data on Nigeria's democratic tradition today. For while in the Nigerian military era, state officers undermined the letters and spirit of the national constitution during which unlawful arrests, wanton display of profligacy in governance and economic/political corruption were the typical defining elements of the characters of national and regional governments, present day results, albeit of scientifically controlled quasi-experimental researches on the so-called current democratic regime, would undoubtedly show that these indicators of impunity, lack of due process and transparency in governance are still very much evident in today's governments in Nigeria. The ease with which state officers squander public funds in fictitious and "wild-goose-chase" public projects, some of which negotiation and execution involve flurry of foreign travels, transcends category and theoretical definitions. Such travels, often very expensive, involve the use of scarce foreign exchange thereby consolidating the depletion of the nation's foreign exchange stock - a depletion process already on course since the ongoing civilian government took off in 1999. The subject matter of transparency in governance remains a very elusive variable to measure in contemporary Nigeria where even policy documents do not tell of the true disposition of state of affairs in Nigeria. Inquiring for instance into "State Budget" as an instrument for measuring the level of transparency in governance in Nigeria would require measuring such variables as the "level of public participation or involvement" in the state budget process (that is, from formulation, implementation to evaluation/appraisal stages). Such studies would call for relevant policy information on the fiscal situations in the state - information which are only made available by the states. Studies like that should help create some sets of political and social indicators such as "level of public availability" of state budget information, the extent to which state institutions provide opportunities for "public participation" throughout the (state) budget process and or the "public availability" of information regarding procurement practices at the state level in Nigeria including knowledge of the "legal framework" on such procurements. While documents containing state government's budgetary information may be available even on the internet websites of the respective governments, ( see for instance www.http://deltastateassembly.gov.ng/2014 and www.lagosstate.gov.ng/ ) physical representation in terms of actual projects/programmes being quoted (or more precisely accounted) for in the budget statements remain elusive. Social researcher may want to use such available data to theorize that there is public availability of budget information and hence public participation/involvement in the budgetary process in Nigeria but that is where their results will once again falter. For while for instance, the state accountants-general or auditors-general reports may clearly articulate government application of public funds during a given time/period of consideration, for which receipts have been duly matched with copious payment evidences to buttress a firm accounting procedure, such records represent a subterfuge and mere paperwork for the purpose of presentation and storage of an illusory record of accountability in governance. Theories would falter in prognosticating on the behavior of state officers on matter of impunity, due process and transparency.

\section{Accounting for the Failure of Research Data in Nigeria}

* POOR INSTITUTIONAL SUPPORT FOR RESEARCH: Philosophically, the social sciences may be argued to have originated in Europe in the eighteenth and nineteenth centuries - think about Smith, Hobbes, Darwin, Locke, Rousseau, Montesquieu, Kant, Comte, Durkheim, Marx and Weber. However, American social science takes the credit for its outstanding early institutional framework for research and development of the discipline think about the American Economic Association (1885) established five years earlier than The Royal Economic Society (originally founded as British Economic Association in 1890); American Political Science Association (1903) considered a much earlier political science group than the British Politics Group (1975) or the European Consortium on Political Research-EPCR (1970), American Sociological Association (founded as American Sociological Society in 1905), and the now very popular American Psychological Association (APA- 1903). All of these bodies have research publication platforms dating over a century and publishing continuously since then - American Sociological Review (1938), American Political Science Review (1906), American Economic Review (1911) among others. Through these platforms, enormous scientific data gathering and research initiatives with institutional support from government, business and other corporate bodies have flourished continuously throughout the twentieth century and now into the twenty-first. How about the debate on: who is more important - the creator (starter) or the developer (finisher) of a product/service? Thus it can be said that the glory of the American social science therefore lies in the enormous institutional support for research and massive 
gathering of "scientific" data it has enjoyed over the years, beside the complex network of faculty or departments spread across the United States and Canada alone where social science is being continuously taught and research in. Without reliable institutional support, it is arduous for anyone to contemplate making a research on local social matter (or any other matter for that purpose) in Nigeria, if only to verify existing theories using local data, let alone creating or developing new ones. It must be acknowledged here however that though the quantum of institutional support locally for scholarship and research has grown in leaps during the democratic era especially in the Goodluck Jonathan regime under the aegis of the Tertiary Education Trust Fund (TETFUND - established by Act of the National Assembly in 2011), in comparative perspective however, much is still to be desired of the sustainability of this arrangement and the complex bureaucracy involved in its distribution and access.

* UNRELIABLE INSTITUTIONAL DATA: A research data is as good as the parent institution or body that sourced it. Where the source of data is un-trusted, the data itself has fundamentally suffered bias. Institutions such as the Population Council,2007 and analysts such as Kwache (2009),Yakasai,(2006) have often relied on the 2006 national population census figures published by a Federal Government of Nigeria agency, the National Population Commission (NPC), or at least made projections on them in their research analyses. Yet even when these international institutions adopt the figures (albeit without more useful alternatives there from) as "official" data in some respect, a lot of compromise had occurred by such adoption on their correctness or near-correct status. Local analysts know that the conduct of national population censuses in Nigeria since independence in 1960 have often suffered from political tinting just as much as the composition or leadership of the population commission (or other national commissions) suffer from the institutionalized disease of "federal character" at the clear expense of merit. Kwache (2009) acknowledging this fact even "...therefore challenge the National Population Commission to conduct a proper a census ...". The challenge of "who" gets "what" and "why/why not" from the "national cake" has often threatened (if not, totally destroyed) the reliability, as it were, of national "policy" data. For instance, Nigeria, in terms of potential national income balance (not merely of national resources), has recently "revalued" its domestic product (GDP) and have perhaps "politically" overtaken South Africa - that has a longstanding international history of economic leadership over Nigeria. But with the latter's unending, high degree of economic volatility and instability especially in its money and capital market scenarios, against the background of its "terrorized" mono-product oil-based economy, local economic analysts and experts would require no less of technical compromise to accept the institutional claim (while not ignoring the possibility of its correctness). The non-reliability of institutional data in Nigeria becomes even more vocal and avowed when viewed on the parlance of domestic politics in the Nigerian state. The enormity of distrust in voting results since independence (with the June 12 presidential election, being perhaps the only arguable exception) provides ample basis for despondency in local research data. The acquisition and supposed use of election card-readers machines for recording and electronically transmitting election results, to a national collating centre may have been a welcome development by many sections as a right step, in minimizing election fraud in Nigeria - a long standing cankerworm in the body-politic of the Nigerian state. However, the enormous debate and struggle between the ruling and opposition parties over its subsequent use / non-use in the 2015 presidential election, only solidarizes the argument that research data (this time, political) cannot be used to successfully "practicalize" research theories in Nigeria.

* USE/NON-USE OF RESEARCH OUTCOMES: Sustained interest in research may vary with environment depending on the degree of social response to the outcomes of such researches. Thus, while enormous efforts may be put into developing new research activities, the utilization of, and attention to, local research findings by policy makers go a long way to arousing fresh interest(s) for research and hence the propensity to insist on valid and reliable data in conducting new researches, where necessary. Where policymakers become indifferent, and pay lip service to research efforts, let alone their findings, as current disposition in Nigeria clearly shows, researchers may easily become complacent at little efforts and despondent at furthering such courses with optimism using more refined and reliable data. Often, research findings are not published, if any, and the recommendations/suggestions for further studies or policymaking ignored with reckless abandon and in some cases derided upon by policymakers and other stakeholders. Even when government initiate research/development outfits to brainstorm and present report on workable policymaking options to deal with a given social or political phenomenon, such reports more often than not get "shelved" permanently before they are ossified or become time-barred. For instance, during a significant part of five months in 2014 (March 18 to August 24), a sprawling extra-legislative and consultative forum known as a 'sovereign national conference' was sponsored (perhaps extravagantly) by the federal government of Nigeria with a mandate to prognosticate on the way forward for the Nigerian nation-state. However, no sooner had the conference reports been presented to the Jonathan government than the latter had been accused of jettisoning its letters and contents in toto. The Jonathan's administration had assured the nation of the adoption of its "relevant" suggestions: "As I receive the 
report of your painstaking deliberations, let me assure that your work is not going be a waste of time and resources. We shall do all we can to ensure the implementation of your recommendations which have come out of consensus and not by divisions"(Premium Times, 2014). The government even followed up this pledge with the appointment of a seven-man presidential working committee to "develop appropriate strategies" and modalities for the implementation of the reports of the just-concluded national conference in early September of 2014. However, the government's lukewarm attitude in this regard soon evidently prompted some of the 'honourable' participants at the aforesaid conference, upon foreseeing the government's debilitating disposition towards the implementation of the conference report, to regroup (this time without government sponsorship) in early January 2015. The regrouping was to impress (unsuccessfully however) on the Jonathan's administration to adopt and implement the reports of the national conference. This is the same attitude towards researches in Nigeria as Research Institutes become moribund and get starved of the required resources (funding and manpower). Many of these institutes are specialized ones initially established with high hopes of providing excellent research and development on chosen aspects of scientific activity especially in crop and animal production. Cargoes of unpublished $\mathrm{Ph} . \mathrm{D}$ theses (let alone other lower-level certificate and degree researches) litter the libraries of Nigeria universities and institutes apparently for academic consultation, if any, at least, and nothing more. With such apparent awareness of the certainty of non-use of research reports, students and other social researchers are thereby offered a leverage on the choice, nature and significance of their research data, if only to meet some mundane programme, academic or institutional requirements. The lack of sustained enthusiasm for further research owing to policymakers' cynical attitude towards, and non-use of, research findings may have significantly affected the relevance of the data options used for verifying existing social theories in Nigeria. Many of these data have been manipulated or technically controlled to provide the expected information suitable only for realizing anticipated research outcome. Majority of such data are not value-free. Theories would under such platforms undoubtedly again falter in predicting social matter.

\section{Conclusion and Recommendations}

The relevance of scientific knowledge in promoting national development cannot be overstretched here. The apparent transition of some hitherto Second-world economies into the First-world industrialized mega-economies such as Japan, China, Singapore can only be explained by the apparent strong determination of policy makers in these nations to, inter alia utilize their national research efforts and those relevant inputs from international researches within the context of their national historical experiences. Nigeria must not necessarily wait for a Hiroshima and Nagasaki experience to stimulate its consciousness towards sustainable national growth and development even if Japan's socio-economic ascendancy could be traced to that mid-twentieth century event. If social research in Nigeria is to be a vital input of national development, then institutional confidence must significantly grow towards the nation's public institutions such as the National Population Commission (NPC), the Independent National Electoral Commission (INEC), the Federal Bureau of Statistics (FBS), the Federal Road Safety Commission (FRSC), The Nigeria Police, the national and state universities, institutes among others. The wave of corruption among public officers and their indifference towards implementation of subtle programmes of national development even when they have been expensively formulated cannot encourage the furtherance of genuine social research in Nigeria as well-meaning research initiatives are daily being shelved by policy implementers for want of national consciousness. The patronage of domestic research would go a long way to fire the enthusiasm towards more meaningful and progressive researches.

The growth of local social research will be boosted by a more robust funding support than what obtains at present. It must however be acknowledged here that the present arrangement by the Tertiary Education Trust Fund (TETFUND) is commendable for its progress so far in promoting local scholarship and research but its efforts must be restructured to make access by genuine prospective researchers and scholars become much easier than the present highly bureaucratized structural framework. Besides, private sector support in promoting scholarly research by individuals or research organizations must begin now more than ever before.

Social research in Nigeria can become exciting and more deterministic if realistic data of the social system are correctly extracted and utilized by trusted institutions and individual researchers. Good governance and the fast move towards national integrity, accountability and consciousness should be the major vehicles for creating a more realistic social research data base on which research can be conducted through which also contemporary social theories could be verified internationally.

\section{References}

Afinotan, L. A., \& Ojakorotu, V. (2009, May). The Niger Delta crisis: Issues, challenges and Prospects. African Journal of Political Science and International Relations, 3(5), 191-198. 
Aluko, M. E. (1994). Re-visiting June 121993 Nigerian presidential election results. Retrieved March 2, 2015, from http://www.nigerianmuse.com

Amoo, S. G. (1997). The challenge of ethnicity and conflicts in Africa: The need for a new paradigm. Report of the United Nations Development Programme, Emergency Response Division, New York.

Attia, P. (2012). What would Richard Feynman do? Retrieved January 25, 2015, from www.eatingacademic.com/

Bertalanffy, L. (1968). General Systems Theory: Foundations, development, applications. New York, George Braziller.

Danjibo, N. D. (2009). Islamic fundamentalism and sectarian violence: The "Maitatsine and "Boko Haram" crises in Northern Nigeria. Proceedings of ABU Conference on the Social sciences, Zaria. Retrieved January 20, 2015, from http://www.ifra-nigeria.org/IMG/pdf

Danjibo, N. D. (2014). Conceptual discourse, literature review and theoretical framework. In I. O. Albert, O. Olasehinde-Williams, \& O. Aremu (Eds.) Research methods in peace and conflict studies (pp. 53). Ibadan, Nigeria: Peace and Conflict Studies Programme, Institute of African Studies, University of Ibadan.

Deutsche Welle. (2014, August 24). Boko Haram declares caliphate in Nigerian town under rebel control. Deutsche Welle (DW). Retrieved February 23, 2015, from http://www.dw.de/

Dollard, J. et al. (1939). Frustration and aggression. Yale University Press, New Haven. http://dx.doi.org/10.1037/10022-000

Easton, D. (1965). A systems analysis of political life. New Jersey, John Wiley.

Ehwarieme, W. (2012). Ethnicity and electoral politics in Nigeria: The case of Delta State, 1999-2011. Journal of Social and Management Sciences, 7(1), 31-39.

Ekpo, A. H., \& Ndebbio, J. E. U. (1988). Microeconomic Theory: Principles and Applications. Calabar: Wusen Press.

Elbadawi, I., \& Sambanis, N. (2000, October).Why are there so many civil wars in Africa? Understanding and preventing violent conflict. Journal of African Economics, 9(3), 244-269. http://dx.doi.org/10.1093/jae/9.3.244

Elbagir, N., Cruickshank, P., \& Tawfeeq, M. (2015). Boko Haram purportedly pledges allegiance to ISIS. CNN News, Sunday March 8, 1100 GMT. Retrieved March 11, 2015, from http://edition.cnn.com/2015/03/07/africa/nigeria-boko-haram-isis/

Horowitz, D. L. (1998). Structure and strategy in ethnic conflict: A few steps toward synthesis. In B. Pleskovic, \& J. E. Stiglitz (Eds.), Proceedings of the Annual World Bank Conference on Development Economics, (ABCDE), 1998 (pp. 345-384). Washington, DC.

Koutsoyannis, A. (1988). Theory of econometrics: An introductory exposition of econometric methods (2nd ed.). Bassingstroke, Hampshire: Macmillan education Books.

Kwache, I. Y. (2009). Population census in Nigeria: The case of Michika Adamawa State. Retrieved March 6, 2015, from http://www.gamji.com/article8000/

Obah-Akpowoghaha, N. G. (2013). Theoretical understanding of conflicts and violence in Nigeria: The Niger Delta militant and northern Islamic sect Boko Haram in perspective. Public Policy and Administration Research, 3(10).

Obanikoro, M. (2014). Obanikoro: Boko Haram Caused by Illiteracy. Retrieved February 23, 2015, from http://www.naij.com/67808.html

Osaghae, E., Ikelegbe, A., Olarinmoye, O., \& Okhonmina, S. (2007). Youth militias, self determination and resource control struggles in the Niger-Delta region of Nigeria. Retrieved March 2, 2015, from http://integritynigeria.org/

Otite, O. (1990). Ethnic Pluralism and Ethnicity in Nigeria. Ibadan: Shaneson.

Parsons, T. (1951). The social system. London: Routledge \& Kegan Paul limited.

Pomeroy, R. (2014). Are there "laws" in the social science? Retrieved January 25, 2015, from www.realclearscience.com/blog.2014/01/

Population Council. (2007). Report of Nigeria's national population commission on the 2006 census. Population and Development Review, 33(1), 206-210. 
Premium Times. (2014). Remarks by President Jonathan on the occasion of the submission of the 2014 National Conference Report. Premuim Times, August 21, Retrieved December 16, 2014, from https://www.premiumtimesng.com/

Rapoport, A. (1984). General system theory: Essential concepts and applications. Tunbridge Wells, Kent: Abacus Press.

Reutlinger, A. (2011). A theory of non-universal laws. International studies in the philosophy of science, 25(2), 97-117. http://dx.doi.org/10.1080/02698595.2011.574853

Rosen, C. L. (2009). Men v. Women: Who does better in a divorce? Retrieved February 2, 2015, from https://www.legalzoom.com/articles

Ryan, S. (1995). The study of programming languages. Prentice hall, Inc.

Scheff, T. et al. (2006). Goffman Unbound!: A New Paradigm for Social Science (The Sociological Imagination). Boulder, Colorado: Paradigm Publishers.

Smart, H. R. (1931). The logic of science. New York: D. Appleton \& Company.

Soddu, C. (2010). Curved spacetime perspective as generative engine. Intersubjectivity \& contrapunctus. GA2010 - XIII Generative Art Conference - Politecnico di Milano University, Italy. Retrieved February 2, 2015, from http://www.generativeart.com/on/cic/ga2010/

Stonier, A. W., \& Hague, D. C. (1972). A textbook of economic theory (4th ed.). London: Longman Group Limited.

Tenuche, M. (2009). Youth restiveness and violence in Nigeria: A case study of youth unrest in Ebiraland. Medwell Journal of the Social Sciences, 4(6), 549-556.

Usman, S. A. (2015). Unemployment and poverty as sources and consequence of insecurity in Nigeria: The Boko Haram insurgency revisited. African Journal of Political Science and International Relations, 9(3), 90-99.

Vande, P. T. (2012). Ethnicity and the politics of state creation in Nigeria. European Scientific Journal, 8(16), 33-51.

Walker, I., \& Smith, H. J. (2001). Relative Deprivation: Specification, development, and integration. Cambridge University Press. http://dx.doi.org/10.1017/cbo9780511527753

Yakasai, S. A. T. (2006). Appraisal of the 2006 provisional census figures. Retrieved March 6, 2015, from http://www.gamji.com/article6000

Zimmerman, K. N. (2012). What is a scientific theory? Retrieved February 10, 2015, from $\mathrm{http}: / / \mathrm{www}$. livescience.com/21491

\section{Copyrights}

Copyright for this article is retained by the author(s), with first publication rights granted to the journal.

This is an open-access article distributed under the terms and conditions of the Creative Commons Attribution license (http://creativecommons.org/licenses/by/3.0/). 